$9-1-2007$

\title{
Saving and Social Security Wealth: A Case of Turkey
}

H. Yigit Aydede

University of Windsor

Follow this and additional works at: https://ecommons.luc.edu/meea

Part of the Economics Commons

\section{Recommended Citation}

Aydede, H. Yigit, "Saving and Social Security Wealth: A Case of Turkey". Topics in Middle Eastern and North African Economies, electronic journal, 9, Middle East Economic Association and Loyola University Chicago, 2007, http://www.luc.edu/orgs/meea/

This Article is brought to you for free and open access by the Journals and Magazines at Loyola eCommons. It has been accepted for inclusion in Topics in Middle Eastern and North African Economies by an authorized administrator of Loyola eCommons. For more information, please contact ecommons@luc.edu. (c) 2007 the authors 


\title{
Saving and Social Security Wealth: A Case of Turkey ${ }^{1}$.
}

\author{
H. Yigit Aydede ${ }^{2}$ \\ University of Windsor \\ January 4-7 2007 Chicago \\ Middle East Economic Association Annual Meeting
}

\begin{abstract}
This paper is the first attempt in the literature to investigate the effects of public social security on aggregate consumption in a time-series setting for a developing country, Turkey that has one of the most generous social security systems in the OECD region. In order to quantify the social security variable, the paper uses the social security wealth (SSW) series calculated for Turkey in a separate study. This study indicates that SSW is the largest part of the household wealth in Turkey and therefore should not be ignored in the aggregate consumption studies. After having all sensitivity tests for the major assumptions embedded in the SSW series, it shows that SSW has robust and positive effects on aggregate consumption, and therefore the PAYG system suppresses the Turkish national saving approximately 25\% in 2003.
\end{abstract}

Acknowledgements: We thank to Laurence Seidman, Jeffery Miller and Kenneth Lewis at the University of Delaware, and Can Karasikli for his invaluable support for finding data resources in Turkey.

Keywords: Social security, saving, aggregate consumption, time-series, social security wealth.

JEL classification: J1, H55, E21

\footnotetext{
${ }^{1}$ This work is supported by the University of Delaware's research fund and the Network Financial Institute's Social Security and Policy Analysis program (at the Indiana State University).

${ }^{2}$ Department of Economics, 401 Sunset Avenue, University of Windsor, Windsor, ON, N9B 3P4, Canada, e-mail: aydede@uwindsor.ca, tel.: (519) 253-3000, ext. 2389.
} 
Public insurance is the single largest item in government budgets and has a significant impact on the lives of thousands of people. In addition to its effect on the living standards of elderly people, Social Security may alter people's behavior in ways that could affect the economy. People who are entitled to some sort of social security payments in the future may prefer to consume more today and save less for their retirement. If public social security is unfunded (pay-as-you-go - PAYG), this decrease in personal saving may even reduce national saving.

There are two types of studies conducted in the literature to see whether or not social security affects personal and national savings: empirical studies and simulations. Empirical studies are based on three types of data sets and therefore might be classified accordingly: time-series, cross-sectional, and cross-country analyses.

This paper is the first attempt in the literature to investigate the saving effect of public social security in a time-series setting for a developing country, Turkey. One reason for this scarcity of studies might be the limited availability of data for developing countries. Even though Turkey is not immune to this sort of problem, it has relatively better data sources and a long history with a public social security system. Another reason could be the difficulty in calculating a proxy that represents an aggregate perception of household social security wealth.

The first step in time-series studies is to calculate the total (aggregated) Social Security Wealth (SSW) series over the years for the economy. SSW is the net present value of the future benefits and contributions with survival probabilities. Since it's a highly concentrated work, we have constructed the SSW series for Turkey from 1970 to 2003 in a separate study (Author, 2005). A simple comparison shows that SSW is the largest part of the total household wealth in Turkey.

A typical aggregate time-series study tests whether, as total SSW changes over time, aggregate saving also changes. Some studies observe changes in consumption, while others look directly at saving. The present study uses an aggregate consumption function in a life-cycle model (LCM) setting (Ando and Modigliani 1963) to investigate whether or not the time-series data provide some evidence for this claim. We extend the pure life-cycle consumption model to incorporate other factors that could influence aggregate consumption, such as uncertainty, credit constraints, unemployment, demographic changes and the interest rate.

The most important aspect of this study is not only that Turkey is a developing country but also that it has one of the most generous social security systems in the Organization for Economic Co-operation and Development (OECD) region. Our estimation results show that SSW has significant and positive effects on consumption, and this could be interpreted as implying that public social security reduces saving in Turkey.

The plan for the paper is as follows. Section 1 provides a brief background on the relationship between saving and public social security and summarizes the time-series literature on the subject. The generosity of the Turkish social security system is discussed in Section 2. Section 3 discusses social security wealth in Turkey. The model and results of the empirical tests are given in Section 4. The conclusions are in Section 5. The Appendix provides a brief summary of the SSW calculations for Turkey. 


\section{Background and Literature Review}

There are two major competing theories for testing whether or not social security or any type of government debt affects savings: the life-cycle model (Modigliani and Brumberg 1954) and the infinite-horizon model (Barro 1974). Agents in the life-cycle model receive utility only from their own consumption and take the whole life-span into account when planning consumption. They reduce their saving if their retirement is financed by levying taxes on the working generation. Whereas the Barro's infinite-horizon model shows that when the life-cycle model is extended with altruistic bequest where agents receive utility from their descendants, saving might not be affected.

The life-cycle hypothesis within a simple two-period overlapping generations setting provides a suitable framework for analyzing the effect of social security on saving where a rational forward-looking worker faces no borrowing constraints, capital market imperfections, and uncertainty. If the worker has a constant labor supply and saves only for retirement, when a social security system is introduced, he dissaves exactly the same amount that he contributes to the system, provided that the implicit rate of return on the taxes (contributions) is equal to the market interest rate. In other words, if the combination of social security contributions and benefits does not alter the individual's lifetime budget constraint, savings will fall by just enough to leave consumption during retirement unchanged. That is, he would substitute one asset for another, because social security and private saving are perfect substitutes. If the rate of return on the taxes is higher (lower) than the market interest rate, the worker dissaves more (less). ${ }^{3}$ If the social security system is unfunded, i.e., if most of the revenue from contributions goes directly to retirees as in PAYG, this reduction in personal saving is not offset by a rise in government saving, and, as a result, national saving falls.

The simple model above assumes that people save only for retirement and do not receive and leave bequests in an environment where capital markets are perfect, the social security benefits are paid in lump sum, and there are no uncertainties in future income streams and life expectancies. Within the framework of a traditional life-cycle model, as we relax these assumptions, the provision of social security may not offset personal saving one-for-one even if the net social security wealth (NSSW) is zero as outlined below.

- Uncertainty. People may not be so certain about their future income stream. With uncertain earnings, households save more for precautionary motives relative to less urgent retirement saving in their early ages. As income uncertainty increases, the negative effect of old-age pension entitlements on personal saving becomes stronger for older people who are close to retirement, but not so for younger population. Thus the offset between social security and private saving tends to be less than one-for-one for younger households but increases as retirement saving becomes more important (Engen and Gale 1997).

\footnotetext{
${ }^{3}$ If the implicit return on contributions (ssr) is equal to the market interest rate $(r)$ then the present value of benefits is equal to present value of contributions, i.e. the net social security wealth (NSSW) zero, when the discounting occurs at the market interest rate. If $s s r>r$ NSSW becomes positive. In this case, social security increases the lifetime budget constraint and consumption in each period would rise. Therefore, private saving would fall by more than the worker's contribution. If NSSW is negative, the opposite occurs. Seidman (1999).
} 
- Capital markets. If financial markets are not well developed, people cannot smooth their consumption by borrowing against their future income. This may increase the need for precautionary saving. As precautionary savings become more important for short-term income risks, the effect of social security provisions on personal savings fades. Likewise, families may have fixed saving goals such as a downpayment for a house. With capital market constraints, they may be forced to reduce their consumption in response to social security payments, which in turn prevents personal saving from falling one-for-one.

- Annuity payments. Benefits are received by annuities not in a lump sum payment at retirement. Annuity payments may not finance unexpected large expenses and cannot be bequeathed to heirs. Therefore social security wealth itself may not be compatible with other types of personal wealth and thus social security contributions may not crowd out personal saving one-for-one.

- Other saving motives. The effect of social security contributions on personal saving depends on the substitutability of personal saving and social security contributions. If households save primarily as a precaution, they will consider social security contributions illiquid since benefit payments will not start before retirement. Therefore, social security will not replace personal saving one-for-one.

- Insurance. Moreover, since annuities provide insurance against the risk of uncertainty about longevity and personal saving cannot offset the insurance part of social security contributions, one might argue that the existence of social security could magnify a reduction in personal saving. ${ }^{4}$

- Retirement effect. When we allow households to vary the amount of labor supply supplied, consumption could be substituted by leisure. As explained in the Feldstein's influential paper (1974), when social security is introduced, individuals may reduce their retirement age. This reduction in turn decreases the lifetime wealth by shortening the earning stream. Therefore, social security induces early retirement and increases personal saving during working years in order to finance longer retirement financial needs. This offsetting retirement effect reduces the power of the asset substitution effect. It is, therefore, theoretically possible that personal saving may even rise if the existing social security system induces a very early retirement age.

- Partial equilibrium. In addition to these partial equilibrium effects, there are general equilibrium effects as well. A reduction in saving may cause a lower capital accumulation and in turn may reduce real wages. A reduction in wages, in turn, may result in a decrease in consumption and an increase in saving. Therefore, as Siedman (1984) shows, general equilibrium effects may dampen effects of social security on saving.

- Attached benefits. Social security wealth calculations ignore attached benefits such as health insurance and unemployment benefits. All these additional benefits can make the social security effects on personal saving stronger.

\footnotetext{
${ }^{4}$ This type of insurance is less available in the private sector due to the adverse selection problem. Empirical studies show clear evidence that there is indeed an adverse selection problem in voluntary annuity markets (Finkelstein and Poterba (2004)).
} 
Cultural factors, lack of urbanization (Novos 1989), inefficient social development, and an uneducated population would make a big difference in expected rational behaviors, which are supposed to be consistent with the life-cycle theory. Furthermore, there is a tension between the justifications for a compulsory social security system and the justification for why social security affects saving: social security (public social saving systems) exists because people are myopic and cannot plan and save for their future. However, social security systems affect personal saving because people are foresighted and adjust their consumption and saving behaviors due to future social security changes. As a result, it is theoretically ambiguous whether future social security entitlements negatively affect saving.

In the literature, empirical studies that study social security effects on savings are based on three different types of data sets and might be classified accordingly: crosssection, time-series, and cross-country analyses. While cross-section researches analyze whether people with relatively high expectations in social security benefits hold relatively low private wealth, time-series analyses calculate the SSW series for the entire economy and then use it to see whether or not the aggregate consumption over time is higher as the SSW gets higher. Cross-country analyses compare different countries to see if the saving rate is linked to the generosity of public social security provisions.

The first time-series analysis was done by Feldstein in 1974. He adopts the consumption function used by Ando and Modigliani (1963) and extends it by adding his new SSW variable. In both of his studies in 1974 and 1996, Feldstein found statistically significant results showing that SSW affects consumption positively. In his influential 1974 paper, he claims that the social security provision reduces personal saving by $30 \%$ to $50 \%$ in the US; while in 1996 he finds that the effect is almost 60\%.

Many time-series studies were done following Feldstien (1974). ${ }^{5}$ Among the most important studies on time-series analyses are the following. Munell (1974) looks at the same issue with endogenous retirement age and finds that a negative effect of benefits on saving is canceled out by a positive effect of early retirement. Darby (1979) uses the money supply and relative price of durables goods in his regression and finds negative effect in most cases. Coates and Humphreys (1999) investigate the linearity of the equation in Feldstein’s (1996) paper. Meguire (1998) disaggregates the personal disposable income by using Kormandi's (1983) augmented consolidated approach and confirms Feldstein's (1996) results. Finally, Blake (2004) uses error correction models and finds that state pensions have a strong saving replacement effect in the UK. A more inclusive list for the literature on time-series studies is given in Table 1.

\footnotetext{
${ }^{5}$ For an extensive literature review on the subject see OECD (1998), Congressional Budget Office (CBO) memorandum (1998), Engen, E. and Gale, W. (1997), and Magnussen (1994).
} 


\begin{tabular}{lccc}
\hline & & & SSW \\
Authors - Country & Sample Period & $\begin{array}{c}\text { Dependent Variable } \\
\text { Consumption }\end{array}$ & S \\
Feldstein (1974) USA & $1930-71$ & Personal Savings & S \\
Munnell (1974) USA & $1929-69$ & Consumption & NS \\
Barro (1978) USA & $1929-74$ & Consumption & NS \\
Darby (1979) USA & $1924-74$ & Pers. Saving/Income & S \\
Markowski and Palmer (1979) Sweden & $1952-75$ & Pers. Saving & NS \\
Boyle and Murrey (1979) Canada & $1946-75$ & Pers. Saving/Income & NS \\
Pfaff, Hurler, Dennerlein (1979) Germany & $1965-78$ & Consumption & NS \\
Leimer and Lesnoy (1982) USA & $1930-74$ & Consumption & NS \\
Browning (1982) UK & $1966-79(Q u a r t e r l y)$ & Pers. Saving \& LFPR & NS \\
Lee and Chao (1988) USA & $1947-77$ & Consumption & S \\
Magnussen (1994) Norway & $1966-90$ & Consumption & S \\
Rossi \& Visco (1995) Italy & $1954-93$ & Consumption & S \\
Feldstein (1996) USA & $1930-92$ & Consumption & S \\
Meguire (1998) USA & $1930-92$ & Consumption & S \\
Coates and Humphreys (1999) USA & $1930-92$ & Consumption &
\end{tabular}

Notes: S and NS denote Significant and Not Significant respectively

Three important criticisms of Feldstein's 1974 paper are Barro (1978), Leimer and Lesnoy (1982), and Auerbach and Kotlikoff (1983). The negative effect of funding structure of a social security program on national saving has been challenged by Barro (1974, 1989). Unlike the life-cycle model, the Barro’s infinite-horizon model assumes that agents are altruistic and care about descendant's consumption as well. Barro claims that the mandatory transfers from young to old could be offset by voluntary transfers from old to young under altruistic bequest motives and therefore funding status does not affect national saving. Barro uses the same SSW data series with three additional major variables: unemployment, government deficit (or surplus), and a new SSW 6 variable in addition to Feldstein's SSW. He concludes that when the new variables are included the SSW coefficient becomes statistically insignificant. Barro grounds this result on two factors: intergenerational transfers offset the fall in saving, and an inept representation of the perception of people by Feldstein's SSW due to aggregation problems. ${ }^{7}$

The main criticism of Feldstein's paper came from Leimer and Lesnoy (1982). They find that the effect is insignificant when they use different methods for the formation of expectations in the perception of benefits. Their criticism can be summarized in three points. First, the regression results are very sensitive to the time frame. Second, small adjustments in the SSW calculation make a big difference in its coefficient. Third, the expectation formation method for the perception of benefits and taxes that Feldstein used is highly speculative. ${ }^{8}$

\footnotetext{
${ }^{6}$ Barro's alternative measure of social security is calculated based on current benefit rates and current worker coverage under social security.

${ }^{7}$ See Auerbach and Kotlikoff (1983) and Seidman (1984).

${ }^{8}$ Feldstein replies both Barro’s (1978) and Leimer and Lesnoy’s (1982) criticisms in Feldstein (1976a, 1976b, 1978 and 1982)
} 
Finally, Auerbach and Kotlikoff (1983), in a simulation, show that time-series coefficients are not stable because of the aggregation problems. They argue that the coefficients of a life-cycle consumption function depend on the individual's age and differ at any point in time. Therefore, if the age structure of a population is not stable, aggregation of individual consumption functions over all households may cause unstable coefficients.

\section{The Turkish Public Social Security System}

The framework for old-age security in Turkey, as in most developing countries, traditionally involves state-managed pension schemes that pay an earning-related defined benefit financed on pay-as-you-go (PAYG) basis. Turkey's social security system consists of three distinct institutions-Social Insurance Institution (Sosyal Sigortalar Kurumu - SSK) for wage earners in private and public sectors, Bag-Kur (BK) for self-employed individuals and farmers, and Retirment Fund (Emekli Sandigi ES) for civil servants — covering different areas of the labor market.

As most PAYG systems in the world, Turkey's PAYG system have created significant fiscal deficits, labor market distortions, and wicked redistribution to higher income groups, without providing adequate income security for the old. The populist social security policies of Turkish governments over the years have impaired the system whose total deficit approached 4.5\% of GNP per year in 2004. Between 1990 and 2003, the present value of the total resources used to finance the deficit of the social security system is almost equal to the total GNP created by Turkey in $2003 .{ }^{9}$

The financial problem of the Turkey's social security system is resulted from both decreasing revenues and increasing expenses. The lack of a minimum retirement age, which had been removed in 1992, has been the major factor for the financial imbalance-Turkey had retirement ages as young as 47 years of age in SSK and 48 years of age in ES, the lowest in the world. ${ }^{10}$ Moreover, Turkey is the only country in the world that simultaneously had very low minimum contribution periods (in some cases as low as 10 years) and high replacement rates (90\% in SSK, 127\% in Bag-Kur, and $106 \%$ in ES) ${ }^{11}$ with a lack of minimum retirement age before the 1999 reform (The World Bank Country Economic Memorandum, 2000).

The weak link ${ }^{12}$ between contributions and benefits before 1999 created an incentive for workers to declare the earnings base for premium at a lower value. The high informal employment due to relatively high statutory contribution rates, the lack of automatic indexation of the contribution ceiling ${ }^{13}$ under high inflation conditions, and the low premium collection rates because of administrative inefficiencies worsened the already financially imbalanced system. As a result, the system became a major fiscal

\footnotetext{
9 "Proposal for Reform in the Social Security System" (2004), Ministry of Labor and Social Security

${ }^{10}$ Minimum ages were very low even before 1999 . The average minimum retirement ages for OECD countries are 64.4 for men and 63.9 for women in 2002 (OECD 2005).

${ }^{11}$ These rates reflects 2004 values and taken from "Proposal for Reform in the Social Security System" (2004), Ministry of Labor and Social Security. P.19

${ }^{12}$ In SSK, pensions were linked to wages paid in the last five years and the same link was even worse in ES and Bag-Kur: only the last year's wages were used to calculate pensions.

${ }^{13}$ The ceiling on wages subject to social security contribution in the fall of 1995 actually fell below the minimum wage.
} 
burden, damaging Turkey's macroeconomic stability. Coupled with other structural problems in the economy, the severe financial crisis early in 1999 forced Turkish government led by the World Bank to reform the impaired social security system in August 1999. This "parametric" reform was intended to achieve the actuarial balance of the PAYG system in the mid-term and to reduce pressure on the borrowing needs of the government.

In summary, the most fundamental characteristics of the Turkish social security system have been its generosity (relative to income) due to very young average retirement ages (in some cases 38 for women and 47 for men ${ }^{14}$ ), low minimum contribution periods, and high replacement rates. As seen in Table 2 below, according to a new research by the OECD (2005), a new entrant in Turkey has $\$ 74,000$ average gross pension wealth with $\$ 2,510$ per capita gross national income, while the same numbers are $\$ 183,000$ and $\$ 35,430$ for the US in 2002. In addition, Turkey's gross replacement rate (87.2\%) is the highest in the OECD region, which has $56.7 \%$ of the same rate as an average. ${ }^{15}$ While this generosity has paved the way for the collapse of the system's actuarial and financial soundness and still presents a big problem for the system's sustainability, one would expect that this generosity would also have strong effects on consumption and saving behaviors of individuals, which in turn may influence macro economic dynamics. It is this generosity that makes the Turkish case special relative to other developing countries in the literature.

Table 2: Pension and Income (2002, in US Dollars)

\begin{tabular}{lcccccc}
\hline & $\begin{array}{c}\text { Per Capita } \\
\text { GNI }\end{array}$ & $\begin{array}{c}\text { Average } \\
\text { Wage }\end{array}$ & $\begin{array}{c}\text { Replacement } \\
\text { Rate }\end{array}$ & $\begin{array}{c}\text { Gross } \\
\text { Pension } \\
\text { Wealth }\end{array}$ & $\begin{array}{c}\text { Relative } \\
\text { Pension } \\
\text { Wealth }\end{array}$ & $\begin{array}{c}\text { Relative } \\
\text { Pension } \\
\text { Level }\end{array}$ \\
Hungary & $\underline{\underline{4}, 100}$ & 4,187 & 75.4 & 55,000 & 11.7 & 72.2 \\
Slovak Republic & 4,080 & 3,031 & 48.6 & 27,000 & 7.9 & 47.9 \\
Czech Republic & 5,880 & 6,306 & 44.4 & 47,000 & 6.9 & 41.7 \\
Mexico & 5,950 & 6,180 & 36.0 & 28,000 & 4.5 & 35.7 \\
Poland & 4,680 & 6,456 & 56.9 & 51,000 & 7.7 & 55.5 \\
Turkey & $\mathbf{2 , 5 1 0}$ & $\mathbf{6 , 5 7 1}$ & $\mathbf{8 7 . 2}$ & $\mathbf{7 4 , 0 0 0}$ & $\mathbf{1 0 . 3}$ & $\mathbf{8 1 . 3}$ \\
United Kingdom & 25,560 & 29,133 & 37.1 & 172,000 & 5.5 & 37.1 \\
United States & 35,430 & 32,360 & 38.6 & 183,000 & 5.2 & 36.5 \\
Canada & 22,610 & 24,756 & 42.5 & 163,000 & 6.1 & 39.9 \\
OECD Average & & & 56.9 & 202,367 & 8.7 & 55.4
\end{tabular}

Notes: Except GNI, the others are taken form OECD (2005). Average Wage: the average annual earning for a production worker. Replacement Rate (men): a pension entitlement (first annuity) as a share of individual's last earning. Gross Pension Wealth (average): the discounted stream of future pension payments for a new entrant in 2002. Relative Pension Level (men): the weighted average of the pension entitlements (first annuity) expressed as a percentage of economy-wide average earnings. Relative Pension Wealth (men): the weighted average of pension wealth as a multiple of economy-wide average earnings. Gross National Income, GNI, is taken from WDI (The World Bank).

\footnotetext{
${ }^{14}$ See “Turk Emeklilik Sisteminde Reform” (The Reform in Turkish Pension System) TUSIAD November 2004 P.108

${ }^{15}$ Excluding Luxemburg which is an outlier with $101.9 \%$ gross replacement rate.
} 


\section{Social Security Wealth Series for Turkey}

The heart of the time-series analyses is the calculation of the aggregate social security wealth (SSW) variable. In a life-cycle setting, the future income should include both pensions and labor income. Since pension annuities are received only by retirees, the rest of the population should form expectations for the future pension entitlements based on their labor income and related social security regulations.

The social security wealth (SSW) is one of the calculations, as a proxy for expected benefits, for measuring the effect of social security on consumption. This proxy represents people's perception of social security benefits that they will have in the future.

The aggregate SSW, which is basically the net aggregate present value of future social security annuities and tax liabilities with survival probabilities anticipated by people, was conceptualized and calculated for the first time by Feldstein in his (1974) paper.

We applied the same methodology used in Feldsetein (1974) paper and calculated the SSW series for 34 years from 1970 to 2003 at 1987 prices for Turkey in a separate study (Author 2005). We choose this period since the data about the demographics of labor market are not readily available for earlier years. The detailed information about the construction of SSW series can be found in Author (2005) and a brief summary is given in the Appendix.

In order to calculate the SSW series, a "reference income" is needed at two points: in the calculation of benefit and tax factors and in the calculation of the first annuities. Since there is no "survey" based "Personal Disposable Income" (PDI) series in Turkey, We have used Net Private Disposable Income (NprvDI) series generated from the national accounts.

We have fist attempted to generate PDI by using national account identities: $P D I \sim \equiv N N P-T X+T R-R E+N I N T^{16}$. However, because of the problems in finding reliable information on the components of PDI above, We use NPrvDI instead. The difference between NprvDI and PDI, as shown below, simply is retained earnings $(R E)$, on which we don't have any data for Turkey.

If we subtract taxes (TX) and add transfers (TR) and net interest payments by government (NINT) from and to both sides of a simple textbook version of the national account identity, we get the following:

\footnotetext{
${ }^{16}$ Net National Product $(N N P)=G N P-$ Depreciation Net Income $(N I)=N N P-$ Indirect Taxes $($ InTX $)+$ Subsidies $P D I=N I-($ Corporate Profits-Corporate Dividends) + Net Interest (NINT) + (Transfers (TR)Contribution to Social Security (SS)) - Personal Taxes (PrsTX)

Since $($ Corporate Profits-Corporate Dividends $)=($ Corporate Taxes $($ CorpTX $)-$ Retained Earnings $(R E))$ $P D I=N I-(\operatorname{CorpTX}+R E)+N I N T+T R-S S T X-P r S T X$ 
$G N P-T X+T R+N I N T=C+I-(T X-G-T R-N I N T)+(N X+N F I)^{17}$

The expression on the left hand side is Gross Private Disposable Income (GprvDI), and the first and second parentheses on the right side are government saving (GS) and foreign sources (FS) respectively. Therefore the above identity becomes

$G \operatorname{PrvDI}=C+I-G S+F S^{18}$

If the consumption of capital $(\mathrm{CoC})$ is subtracted from both sides, we get

$N \operatorname{PrvDI}=N N P-T X+T R+N I N T$

As seen from this identity, the difference between NprvDI and PDI is RE. Therefore, as long as individuals perceive undistributed profits as capital gains (hence a part of their income), the difference between NprvDI and PDI could be insignificant ${ }^{19}$. We use the following NprvDI definition as reference income series in the SSW calculations and regressions ${ }^{20}$.

$N p r v D I=C+I-G S+F S-C o C$

We have generated several different SSW series by using alternative assumptions and parameters. First of all, as explained in the Appendix, we apply three different types of expectation method in the formation of SSW series. In addition to that, we use two different discount rates: $3 \%$ and $5 \%$. We found the growth rate for the per capita NprvDI to be $1.88 \%$, so we use $2 \%$ income growth rate for the 34 -year period. Finally, we assume that annuities after retirement can grow either by $2 \%$ (same as income) or remain the same so that the nominal increase can be as much as the price inflation.

\footnotetext{
${ }^{17}$ GNP, Gross National Product; C, Consumption; I, Investment; G, Government Expenditures; NX, Net Export; NFI, Net Factor Income from the rest of the world.

${ }^{18}$ GprvDI is also calculated by the State Planning Organization (SPO) in Turkey since 1987, using similar methods, in a table called as "General Macro Balance of the Economy",.

${ }^{19}$ See Feldstein (1974), Ando and Modigliani (1963) and Barro (1978).

20 The consumption, investment and consumption of capital series are taken from OECD database, GS is from State Planning Organization (SPO) and FS is from SPO and World Development Indicators (WDI from the World Bank).
} 
Table 3: Total Wealth in Financial Assets, Housing and SSW with NPrvDI (Million TL in 1987 Prices)

\begin{tabular}{lrlrrr}
\hline & \multicolumn{1}{c}{ TFA } & Housing & \multicolumn{1}{c}{ SSWG } & \multicolumn{1}{c}{ SSWN } & \multicolumn{1}{c}{ NPrvDI } \\
$\mathbf{1 9 7 0}$ & $7,588,518$ & $32,700,333$ & $54,350,527$ & $43,721,351$ & $25,592,525$ \\
$\mathbf{1 9 7 5}$ & $10,806,548$ & $41,781,557$ & $89,508,490$ & $69,086,105$ & $33,269,315$ \\
$\mathbf{1 9 8 0}$ & $9,674,345$ & $56,696,805$ & $63,905,043$ & $33,945,697$ & $42,029,239$ \\
$\mathbf{1 9 8 5}$ & $20,075,898$ & $63,750,469$ & $62,728,296$ & $24,296,819$ & $45,873,753$ \\
$\mathbf{1 9 9 0}$ & $26,996,582$ & $88,709,913$ & $111,574,201$ & $65,316,832$ & $67,179,895$ \\
$\mathbf{1 9 9 5}$ & $46,704,601$ & $128,391,319$ & $103,123,054$ & $49,536,263$ & $84,157,732$ \\
$\mathbf{1 9 9 6}$ & $61,819,289$ & $135,536,058$ & $171,916,203$ & $119,046,643$ & $86,040,622$ \\
$\mathbf{1 9 9 7}$ & $69,998,934$ & $152,101,623$ & $231,487,100$ & $160,536,942$ & $92,590,536$ \\
$\mathbf{1 9 9 8}$ & $75,985,989$ & $160,030,906$ & $277,262,042$ & $185,039,302$ & $102,044,735$ \\
$\mathbf{1 9 9 9}$ & $96,063,696$ & $159,652,714$ & $292,422,907$ & $198,503,687$ & $102,748,644$ \\
$\mathbf{2 0 0 0}$ & $95,036,365$ & $159,160,494$ & $276,903,910$ & $185,179,981$ & $103,808,861$ \\
$\mathbf{2 0 0 1}$ & $146,103,010$ & $165,728,972$ & $270,810,987$ & $198,497,777$ & $100,472,296$ \\
$\mathbf{2 0 0 2}$ & $126,833,322$ & $158,074,788$ & $297,929,986$ & $236,761,695$ & $98,286,544$ \\
$\mathbf{2 0 0 3}$ & $117,491,297$ & $166,061,466$ & $342,736,721$ & $283,310,716$ & $105,211,662$
\end{tabular}

Notes: SSW series are calculated by 3\% discount rate, $2 \%$ growth rate (income) with the "current benefit factor" method. Total Financial Assets (TFA) is calculated by Turkish State Planning Organization (SPO) for the entire economy regardless of who holds them. Housing wealth is an approximation (Author, 2005).

The most important thing to observe is the magnitude of the SSW series relative to NPrvDI and other wealth measures. This fact can be seen in Table 2 above. This observation supports the argument that the social security wealth variable could be an important determinant in saving and consumption studies. This result is also consistent with the U.S social security wealth series done by Feldstein (1974) and Leimer and Lesnoy (1982).

\section{Empirical Results}

As mentioned before, we use an aggregate consumption function in a pure LifeCycle model setting as a baseline model to investigate whether or not the time-series data provide some evidence for the claim that an unfunded social security system has positive effects on consumption, and thus, negative effects on saving. We also extend the model to incorporate other factors, which possibly influence aggregate consumption, such as uncertainty, unemployment, demographic changes, interest rate, and borrowing constraints.

\subsection{The Model and Data}

A rational, forward-looking Household $(\mathrm{HH})$, with inelastic labor supply, maximizes its following lifetime utility subject to its lifetime budget constraint in a perfect capital market without uncertainty:

$U(t)=\sum_{t=0}^{T-i}(1+\rho)^{-t} \log C_{t}$ 
$\sum_{t=0}^{T-i} C_{t} /(1+r)^{t} \leq W_{t}+\sum_{t=0}^{T-i} H W_{t} /(1+r)^{t}+S S W_{t}$

$\boldsymbol{T}$ is the age of death and $\boldsymbol{i}$ is the age of household. For example, if the individual is 25 years old and $T$ is 85 , then the maximum life duration for the individual is $T-i=60$. $C$ denotes consumption and $\boldsymbol{W}$ is real wealth, which is directly observable and consists of housing wealth and financial assets. $\boldsymbol{S S W}$ is discounted present value of future benefits with survival probabilities for every household. The retirement age is given by the law and the maximum life $(T)$ might be truncated at 85 .

$\boldsymbol{H W}$ is human wealth and not directly observable. It's the present value of current and future labor incomes. Since it includes social security taxes, SSW may be taken as gross.

The solution for this maximization problem is

$$
C_{t}=d^{t}\left[\frac{W_{t}}{\sum_{t=0}^{T-i}(1+\rho)^{-t}}+\frac{\sum_{t=0}^{T-i} H W_{t} /(1+r)^{t}}{\sum_{t=0}^{T-i}(1+\rho)^{-t}}+\frac{S S W_{t}}{\sum_{t=0}^{T-i}(1+\rho)^{-t}}\right],
$$

where $d=\left(\frac{1+r}{1+\rho}\right)$.

Since we further assume that the personal discount rate, $\rho$, is equal to the real interest rate, $r, d$ drops out. When we aggregate this individual solution over all households, the resulting function can be represented by the following average (aggregate) consumption function for the entire economy. ${ }^{21}$

$$
C_{t}=\beta_{0}+\beta_{1} Y_{t}^{e}+\beta_{3} W_{t}+\beta_{4} S S W_{t}
$$

$C$ represents consumption expenditures for households, $Y^{e}$ is the present value of current and expected future income, $W$ is the non-human household wealth and SSW is the social security wealth.

We start the empirical test with the above baseline aggregate consumption, which is used in Feldstein's studies both in 1974 and in $1996 . \quad$ In this application, the consumption expenditures include durable goods for the entire period between 1970 and 2003. This is because there is no information on the disaggregated household consumption prior to 1987. Since we estimate only long-term dynamics between the consumption and other variables by the equation above, the inclusion of durable goods in the consumption expenditures does not present a problem. ${ }^{22}$ "Income", $Y$, was first defined in Modigliani’s LCT study in 1963 as “labor income”. However, because of

${ }^{21}$ See Ando and Modigliani (1963) and Auerbach and Kotlikoff (1983).

${ }^{22}$ See Mehra (2001). 
the difficulties involved in calculating implicit labor income for self-employed people, "personal disposable income" (PDI) has been used as an alternative measure in later consumption studies ${ }^{23}$. We use Net Private Disposable Income (NprvDI) in the regressions in the absence of survey based PDI in Turkey. Nevertheless, PDI or NPrvDI is not a perfect measure for LCM: they both include non-human incomes and transfers, and therefore, constitute double counting. Since the expected future income is not directly observable, we use the following rational expectation method in which the current income is unknown and equal to the expectation of current income and a forecast error $(\varepsilon)$ with the standard assumptions $N I I D \sim(0,1)$, as expressed below.

$Y_{t}=Y_{t}^{e}+\varepsilon_{t}=E\left(Y_{t} / I_{t-1}\right)+\varepsilon_{t}$

$Y_{t+k}^{e}=\beta Y_{t}^{e}$ where $\beta \cong 1$

Households form their expectations at time $t$ by using the available information $(I)$ at time $t-1$ and it is assumed that expected future income is proportional to expected current income ${ }^{24}$.

There is no ready-to-use wealth series for households in Turkey, and we have a range of problems in estimating both financial and housing wealth for households. In private equity markets, for example, the first stock exchange, ISE, was formed in 1986. Likewise, private pension funds are very new and not significant. Since the free float in the Turkish market is significantly lower than $30 \%{ }^{25}$ (of the total outstanding equity), the market capitalization is not an appropriate indicator for measuring the private equity market even for the entire economy. Besides, the share of foreign investors in the market is very high (approximately 50\%) and the available information about the household holdings in stocks is very limited.

Before 1980, since the interest rates on deposits were not free, they are not able to reflect the "true" nominal rates under the conditions of high inflation and political instability. Therefore, it is not unreasonable to assume that the wealth was held mostly in gold and housing by households before the liberalizations of the financial markets (during the early 1980s). Since there are no available data, estimating gold holdings of household is quite speculative for Turkey.

Moreover, after 1988, increasing needs in government borrowings made government bonds one of the most demanded investment means for domestic investors. However, since new accounting standards were put into effect in the banking sector only after 2001, there is no reliable record for households' holdings in government bonds prior to that year.

The only adequate data among the household financial assets are on bank deposits, which is the most common financial investment tool for ordinary households particularly prior to 1990s. Therefore, we use the most common proxy for the financial wealth used in the aggregate time-series consumption and saving investigations for Turkey ${ }^{26}$ : real money balances measured by Money-Quasi money (M2).

\footnotetext{
${ }^{23}$ See Blinder et al. (1985), Darby (1979), Feldstein (1974 and 1996), Modigliani (1983).

${ }^{24}$ See Ando and Modigliani (1963) and Mehra (2001).

${ }^{25}$ The World Bank Country Report (2003)

${ }^{26}$ See Akkoyunlu (2002), Ozcan et al. (2003)
} 
The second and most important part of household wealth is housing. The shallow financial markets (particularly before the liberalization in the early 1980s), high inflation and political instability made housing the most popular investment tool for households in Turkey. However, the available data on the number of existing dwelling units and their values are very limited. The only available data for each year on housing are the number of occupancy permits for each dwelling unit and their values. The total stock of dwelling units for each year between 1970 and 2003 can be estimated if the initial stock is known in 1970 and illegal constructions are ignored for the entire period in question. Even though the high urbanization cast doubts on this assumption, we use the relevant data from the State Institute of Statistics (SIS) as checkpoints in generating an approximation of the stock of dwelling units ${ }^{27}$.

In the life-cycle theory, non-human wealth, which is a part of total lifetime resources, contributes to consumption by its anticipated "purchasing power". This purchasing power is divisible into two parts: the additional income that wealth earns and the consumption of this wealth itself (Hamburger 1955). In an economy with superficial financial markets (without mortgage markets) and high bequest motives, the second part of the purchasing power of housing wealth, i.e., the consumption of housing wealth itself, could be considered weak relative to that of more developed economies. Therefore, property incomes might be a better proxy for housing wealth than the total value of the dwelling units in measuring the anticipated "purchasing power" of the housing wealth. Therefore, instead of using an "approximated" total value of dwellings as a proxy for housing wealth, we use "Ownership of Dwellings" 28 , which consists of direct and imputed incomes (net of inputs, representing the added value) of owners from their dwellings.

The baseline consumption function, Equation (2), omits potentially important factors that may influence consumption behaviors: credit constraints, demographic trends, uncertainty, the separation of non-human wealth in terms of liquidity, and the real interest rate. Therefore, we extend this baseline consumption function as follows

$$
\begin{aligned}
& C_{t}=\beta_{0}+\beta_{1} Y_{t}^{e}+\beta_{2} S S W_{t}+\beta_{3} H W_{t}+\beta_{4} F W_{t}+\beta_{5} C R T P_{t}+\beta_{6} R_{t}+\beta_{7} I n f_{t}+\beta_{8} \text { Old }_{t}+\beta_{9} \text { Young } \\
& +\beta_{10} L F P R_{t}+\beta_{11} U r b a \eta_{t}+\beta_{12} U n_{t}
\end{aligned}
$$

where $H W$ denotes the housing wealth using "Ownership from Dwellings", $F W$ is financial wealth, which is proxied by the Money-Quasi Money (M2), and CRPT is "credit to private sector" representing the credit constraints. Inf is unexpected inflation, as a proxy for uncertainty, calculated by the difference between the current and 3-year moving average consumer price inflation.

The real interest rate, $R$, is calculated by adjusting nominal interest rates on oneyear time deposit accounts ${ }^{29}$. While $R$ has two well-known effects on consumption, substitution and income, it has a special importance in our case: all coefficients are affected by a common factor, the real interest rate, as seen in Equation (1).

\footnotetext{
${ }^{27}$ See Author(2005)

${ }^{28}$ It's from the National Accounts by Production, State Institute of Statistics (SIS).

${ }^{29}$ Intr $_{t}=\left(\frac{i_{t}-\pi_{t}}{1+\pi_{t}}\right)$, where $i$ denotes nominal rates, and $\pi$ is the consumer price inflation.
} 
Demographic variables have important roles in the life-cycle consumption models. The stability of averaged coefficients in Equation (2) depends on how quickly the demographic changes occur. Besides, according to LCM, while the young and elderly consume more relative to their income, working age people are supposed to save more and consume less ${ }^{30}$. We use Old and Young as dependency ratios, which are the ratios of the number of people (people younger than 15 and older than 64) to the working-age population (those ages 15-64), to see if their effects are different. Another demographic variable, the ratio of urban population to the total population denoted by Urban, could also be an important factor: a higher urbanization could lead to a decrease in precautionary saving, and therefore a higher consumption could be expected.

Unemployment rate, Un, is used by Ando and Modigliani (1963) as a part of permanent income. As Barro (1978) indicates, it would have a positive effect on current consumption, if future income were positively related to the unemployment rate given the value of current income and other factors. In other words, according to LCM, when people are unemployed, they smooth their consumption by reducing their saving, since they could anticipate that the current income is below the permanent income. On the other hand, a high unemployment rate, which is a common observation in most developing countries, might indicate uncertainty about the future income and therefore suppress consumption (Feldstein 1978). Its effect on consumption, therefore, is not necessarily positive.

The labor force participation rate, $L F P R$, is supposed to affect the relationship between consumption and social security wealth: as the SSW increases it may push consumption up. However, a higher SSW can create downward pressure on LFPR and this may pull consumption down.

\subsection{Estimations}

As pointed in several time-series aggregate consumption studies ${ }^{31}$, the consumption equations, which are linear in levels, may suffer from heteroskedasticity, with or without unit roots, simply because of economic growth that causes the residual variance to increase with time. Feldstein $(1974,1996)$ applies linear models in levels. Meguire (1998) criticizes this approach by pointing out that "neither logged nor weighted" (p.342) time-series linear models in levels may have heteroskedasticity problems, which should be corrected. He uses weighted series by the lagged level of dependent variable in his models. Coates et al. (1999) refer to the same problem in their investigation of social security and prefer to apply models linear in levels. We also test for heteroskedasticity in all estimations, which are linear in levels, by the White test. We then decided to use levels. The first results are given in Figure 1 below.

\footnotetext{
${ }^{30}$ See Modigliani (1986), Darby (1979).

${ }^{31}$ See Mehra (2001), Coates and Humphreys (1999), Campell and Mankiw (1989), Meguire (1998).
} 
Figure 1: Estimation Results with SSWG

\begin{tabular}{|c|c|c|c|c|c|c|c|}
\hline Equations & 1 & 2 & 3 & 4 & 5 & 6 & 7 \\
\hline \multirow[t]{2}{*}{ Income } & 0.62683 & 0.52183 & 0.59112 & 0.41034 & 0.30530 & 0.28483 & 0.16886 \\
\hline & 0.05022 & 0.08141 & 0.071569 & 0.11616 & 0.07512 & 0.06942 & 0.07947 \\
\hline \multirow[t]{2}{*}{ SSWG } & 0.00385 & 0.01913 & 0.02114 & 0.01256 & 0.01222 & 0.01917 & 0.02346 \\
\hline & 0.00879 & 0.01219 & 0.010564 & 0.01081 & 0.00845 & 0.00827 & 0.00879 \\
\hline \multirow[t]{2}{*}{ HW } & 1.95662 & 1.66721 & 2.45531 & 0.62445 & 1.41514 & 1.55203 & 1.27313 \\
\hline & 0.45026 & 0.60926 & 0.427775 & 0.88683 & 0.35125 & 0.32706 & 0.35279 \\
\hline \multirow[t]{2}{*}{ FW } & $(0.05544)$ & $(0.18854)$ & $(0.22163)$ & $(0.23044)$ & $(0.14375)$ & $(0.17374)$ & $(0.18193)$ \\
\hline & 0.07163 & 0.08842 & 0.07057 & 0.11091 & 0.06603 & 0.06181 & 0.06520 \\
\hline \multirow[t]{2}{*}{$\mathbf{R}$} & - & - & - & $(102,348.10)$ & $(119,396.40)$ & $(110,872.60)$ & $(135,338.50)$ \\
\hline & & & & $71,917.01$ & $43,173.77$ & $39,755.31$ & $42,421.80$ \\
\hline \multirow[t]{2}{*}{ CRTP } & - & - & - & 0.33059 & 0.47303 & 0.47787 & 0.55697 \\
\hline & & & & 0.13601 & 0.09655 & 0.08858 & 0.09575 \\
\hline Inf & - & - & - & (185.50) & & - & - \\
\hline \multirow[t]{2}{*}{ Old } & - & - & - & $(143,050.20)$ & & - & - \\
\hline & & & & $109,456.40$ & & & \\
\hline \multirow[t]{2}{*}{ Young } & - & - & - & $(36,754.32)$ & & - & - \\
\hline & & & & $23,516.29$ & & & \\
\hline LFPR & - & - & - & $\begin{array}{l}\mathbf{8 , 9 3 2 . 3 5} \\
5,695.40\end{array}$ & & - & - \\
\hline Un & - & - & - & $\begin{array}{c}(\mathbf{6 2 7 , 7 9 9 . 9 0 )} \\
608,390.20\end{array}$ & & - & - \\
\hline Urban & - & - & - & $\begin{array}{c}\mathbf{( 2 0 , 7 3 7 . 4 9 )} \\
14,950.77\end{array}$ & & - & - \\
\hline \multirow[t]{2}{*}{ Time } & - & $4,081.28$ & $3,457.18$ & $22,370.24$ & 7,539.39 & $8,054.35$ & $10,521.57$ \\
\hline & & $2,752.08$ & 2,153.01 & $11,557.03$ & $1,901.79$ & 1,757.21 & 1,966.36 \\
\hline \multirow[t]{2}{*}{ Dummy95 } & - & $44,884.28$ & $42,615.37$ & - & - & $53,414.29$ & $57,871.49$ \\
\hline & & $24,816.18$ & $18,034.58$ & & & $21,982.47$ & $23,207.58$ \\
\hline \multirow[t]{2}{*}{ Constant } & $146,748.80$ & $236,464.60$ & $123,574.00$ & $2,701,405.00$ & 321,834.10 & $320,572.00$ & $402,502.20$ \\
\hline & $60,249.83$ & $78,831.86$ & $66,485.42$ & $1,740,420.00$ & $60,892.92$ & $55,855.17$ & $62,823.22$ \\
\hline \multirow[t]{2}{*}{ AR(1) Rho } & - & 0.51454 & 0.74580 & - & - & - & - \\
\hline & & 0.20631 & 0.171172 & & & & \\
\hline AR(2) Rho & - & - & $\begin{array}{c}\mathbf{( 0 . 6 0 4 0 2 )} \\
0.18203\end{array}$ & - & - & - & - \\
\hline DW & 1.14370 & 1.53819 & 1.79157 & 2.29047 & 1.96714 & 1.86096 & 2.13010 \\
\hline $\mathbf{R} 2$ & 0.96475 & 0.97194 & 0.97732 & 0.98108 & 0.98171 & 0.98461 & 0.98289 \\
\hline SSR & $25.1 E+9$ & $16.2 E+9$ & $11.5 E+9$ & $9.3 E+9$ & $11.7 E+9$ & $9.5 E+9$ & $10.5 E+9$ \\
\hline $\mathbf{W}$ & 0.04213 & 0.09371 & 0.73767 & 0.65525 & 0.12718 & 0.45301 & 0.36136 \\
\hline $\mathbf{L M}$ & - & 0.01186 & 0.56409 & - & - & - & - \\
\hline
\end{tabular}

All variables are deflated to 1987 prices $^{32}$ and divided by population. SSW series are gross and calculated by $2 \%$ income growth and $3 \%$ discount rates. The benefit factors and coverage ratios used in SSW calculations are not average (constant) and change every year. Standard errors are presented below the coefficients. R2 is adjusted R2. SSR denotes the sum of squared residuals and negative numbers are in

\footnotetext{
${ }^{32}$ Except for the unexpected inflation, interest rate and all ratios. By calculation, SSW series are per capita and in real terms.
} 
parentheses

We use a dummy variable, Dummy95, to take care of the outlier ${ }^{33}$ in 1995, which is identified by observing the recursive residuals. ${ }^{34}$ We also applied a dummy variable for economic recessions and found that it's statistically insignificant.

The first equation is without a correction for its apparent autocorrelation problem. The series in Equations 2 are transformed by the first-degree autoregressive AR(1) process. ${ }^{35}$ We suspect that the specification of autocorrelation might be different than the AR(1) process. Even though it is not possible to know the exact form of autocorrelation, we add $\operatorname{AR}(2)$ to equation 2 and obtain the results in equations 3 . When the series are transformed by the $\mathrm{AR}(1)$ procedure, the first observations are lost. Therefore we also applied Prais-Winsten transformation (with AR(1) scheme) to save the first observations. We found insignificant differences in the coefficients with and without the first observations, and therefore the results are not presented here. In equation 4 , we use the full scale of variables.

Since the DW statistic is not strictly applicable with autoregressive transformations, we also use the Breusch-Godfrey test to diagnose a possible autocorrelation, which is presented by the probability that there is no first-degree autocorrelation and denoted by LM in Figure 1 above $^{36}$. The results of White test ${ }^{37}$ the probabilities that the estimations don't suffer from heteroskedasticity — are shown next to $\mathrm{W}$.

As seen in Equations 4, except for CRTP, the new variables do not contribute to the baseline consumption function defined in Equation (1) before. Very low pair wise correlations show that their insignificances are not merely due to their collinearity with each other. In equations 5 and 6 , we remove the insignificant new additional variables ${ }^{38}$ and add the dummy variable in equation (6).

Since income is defined as $N p r v D I=C+I-G S+F S-C o C$, there might be a simultaneity problem. Therefore, in equation 7, we use GS, FS and $I$ as instrumental variables and apply two-stage least squares (TSLS). This application improves the DW statistics as expected.

The first observation of all equations shows that the SSW variable has a stable positive sign consistent with the model. Even though equation 3 improves the significance of SSW, equations 1, 2 and 3 most likely suffer from possible specification problems.

In equation 4, although not significant, the signs of demographic variables,

\footnotetext{
${ }^{33}$ A severe economic crisis took place in 1994 with a 9-percent decrease in per capita real NprvDI. In 1995 it turned up with a 4-percent growth rate.

${ }^{34}$ We plotted the recursive residuals (for Equation 1 in Figure 5), i.e., one-step-ahead prediction errors (see Johnston and Dinardo. 1997. p. 118) about the zero line. Residuals outside the two standard error bands are identified as outliers. We have two outliers: 1987 and 1995. However, a dummy for 1987 turned out to be insignificant with very high probability.

${ }^{35}$ We assume that the error term follows the first-order autoregressive scheme in Equations 2 as follows: $\mu_{t}=\rho \mu_{t-1}+\varepsilon_{t}$ where $\varepsilon$ is a white noise process.

${ }^{36}$ In computing LM statistics, we took the length of lags for residuals 1 with AR(1) and 2 for AR(2).

${ }^{37}$ Without cross terms

${ }^{38}$ We applied the Wald test and got very high p-values for the null hypothesis that the coefficients of all removed variables are jointly zero, except $R$
} 
Urban, Young and Old, contradict the model's predictions. ${ }^{39}$ As pointed in Ozcan et al. (2003), this can be explained by the extended families under the poor economic and financial conditions in Turkey. The increased number of dependent children and elderly may reduce family resources, increase the economic burden, and pull the consumption down. As for the urbanization, the rapid increase in the urban population makes the living conditions in cities worse for new comers. Therefore, a high urbanization in a short time may create an additional income uncertainty with the effect of reducing consumption.

The sign of the proxy for financial wealth, $F W$, does not agree with the model's prediction in all regressions. However, there may be several reasons for this: the first reason could be that the M2 series may not be a good proxy for the financial wealth held by the private sector. As explained earlier, after the financial liberalization in the markets, the money held by the private sector is mostly invested in short term government bonds. Another reason might be that M2 is also an indicator for the financial depth in an economy. Therefore, an increase in M2 can trigger higher savings and therefore lower consumption ${ }^{40}$. Likewise, under the high inflation conditions, a higher expected inflation may reduce real interest rates (given inelastic nominal rates, which is especially true before the 1980s in Turkey) and therefore depress savings and draw consumption up ${ }^{41}$. When the prices fall down (or a decrease in expected inflation), which increases the real money balance in the markets, people save more and consume less due to the increased real interest rates. Thus, through the price levels, the real money balance could be negatively related to consumption.

Housing Wealth $(H W)$ variable, which is represented by the income from dwellings is statistically significant in all estimations, except for equation 4. As explained before, this result is consistent with the fact that even though housing is the major investment tool for households, it's mostly bequeathed in Turkey. Therefore the imputed income from the housing wealth has a significant effect on consumption.

As explained before, if people can borrow more against their future income and current illiquid assets, they have more sources to consume. The significant relationship between consumption and CRTP confirms this argument. Moreover, the real interest rate has a negative and significant sign, which shows that substitution effect overweighs the income effect. Although insignificant, the sign of unexpected inflation agrees with the models prediction. Likewise, the rate of unemployment is insignificant and negatively related to the consumption level, indicating that the future income uncertainty embedded in unemployment prevails under poor financial and economic conditions.

Among the equations 5, 6 and 7 in Figure 1, equation 6 has better test measures relative to others in terms of R2 and SSR. Moreover, the inclusion of the dummy variable improves Akaike and Schwarz criterions. Its DW statistics is 1.8609, which is slightly higher than the upper level (1.86; $\mathrm{n}=34, \mathrm{k}=8$ with 0.01 significance level).

As Blinder et al. (1985) pointed, the important results should not be sensitive to the choice between linear and logarithmic forms. Therefore, equation 6 is re-estimated

\footnotetext{
${ }^{39}$ Akkoyunlu (2002) and Ozcan et.al (2003) find similar insignificant results for demographic variables in their consumption and saving studies for Turkey .

${ }^{40}$ Ozcan et al. (2003) find a significant positive effect of M2/GDP on private savings in Turkey

${ }^{41}$ Akkoyunlu (2002) indicates that inflation in Turkey has positive effects on consumption.
} 
with the logarithmic transformation (except for real interest rate). As seen in Figure 2 below, the SSW variable is statistically significant with $10 \%$ significance level.

Figure 2: Estimation with Log Transformation

\begin{tabular}{|c|c|c|c|c|c|c|c|c|c|}
\hline Variable & C & $\mathbf{Y}$ & SSWG & HW & FW & $\mathbf{R}$ & CRTP & DUMMY95 & Time \\
\hline Coefficient & 7.4326 & 0.3156 & 0.0378 & 0.1154 & $(0.1450)$ & $(0.0928)$ & 0.1448 & 0.0115 & 0.0487 \\
\hline Std. Error & 1.2565 & 0.0912 & 0.0191 & 0.0249 & 0.0419 & 0.0503 & 0.0287 & 0.0025 & 0.0240 \\
\hline t-Statistic & 5.9153 & 3.4617 & 1.9759 & 4.6416 & $(3.4576)$ & $(1.8446)$ & 5.0476 & 4.6452 & 2.0319 \\
\hline Prob. & 0.0000 & 0.0019 & 0.0593 & 0.0001 & 0.0020 & 0.0770 & 0.0000 & 0.0001 & 0.0529 \\
\hline Adjusted R-squared & \multicolumn{4}{|c|}{0.98271 Durbin-Watson stat } & 1.763567 & & & & \\
\hline Sum squared resid & \multicolumn{4}{|c|}{ 1.13E-02 F-statistic } & 235.3797 & & & & \\
\hline
\end{tabular}

The SSW variable has a significant positive sign in equation (6), which confirms that the social security wealth has a positive effect on consumption, thus negative effect on saving. The results, in Figure 3 below, show that the net or gross definition of SSW does not alter the sign agreement and significance level of SSW. This result is also consistent with the notion that the future taxes are included in the expected future income and therefore the correct measure should be gross social security wealth, as indicated in Feldstein's $(1974,1996)$ results.

Figure 3: Estimation Results with SSWN

\begin{tabular}{|c|c|c|c|c|c|c|c|c|c|}
\hline Variable & C & $\mathbf{Y}$ & SSWN & HW & FW & $\mathbf{R}$ & CRTP & DUMMY95 & Time \\
\hline Coefficient & 300,004 & 0.3126 & 0.0165 & 1.6587 & $(0.1653)$ & $(112,334)$ & 0.4949 & 49,561 & 7,688 \\
\hline Std. Error & 55,934 & 0.0675 & 0.0076 & 0.3392 & 0.0617 & 40,202 & 0.0900 & 21,814 & 1,721 \\
\hline t-Statistic & 5.3636 & 4.6293 & 2.1653 & 4.8893 & (2.6783) & $(2.7943)$ & 5.4999 & 2.2720 & 4.4667 \\
\hline Prob. & 0.0000 & 0.0001 & 0.0401 & 0.0000 & 0.0129 & 0.0098 & 0.0000 & 0.0320 & 0.0001 \\
\hline Adjusted R-squared & 0.98425 & & Durbin & A I & tat & 1.82 & & & \\
\hline Sum squared resid & $9.68 \mathrm{E}+09$ & & F-statis & & & 258.81 & & & \\
\hline
\end{tabular}

As pointed before, the SSW series are calculated with the "current factors" method and 3\% discount rate in Figure 1. However, the regression results should be tested against these assumptions embedded in the SSW calculations.

\subsection{Tests of Assumptions}

As explained earlier, we used three alternative expectation methods in calculating the SSW series: the average (constant), adaptive, and current benefit (and tax) factor methods. Since there are strong negative trends in both benefit and tax factors, we used only the adaptive and current factor methods. The results in Figure 1, 2 and 3 were found by the current benefit and tax methods. Therefore, Figure 4 below shows only the adaptive expectation results.

Figure 4: Estimation Results with Adaptive Expectations

\begin{tabular}{|c|c|c|c|c|c|c|c|c|c|}
\hline Variable & C & $\mathbf{Y}$ & SSWG & HW & FW & $\mathbf{R}$ & CRTP & DUMMY95 & Time \\
\hline Coefficient & 330,511 & 0.2706 & 0.0189 & 1.4512 & $(0.1655)$ & $(107,168)$ & 0.5053 & 49405.3 & 8,243 \\
\hline Std. Error & 57,941 & 0.0740 & 0.0091 & 0.3321 & 0.0636 & 41,307 & 0.0912 & 22,008 & 1,889 \\
\hline t-Statistic & 5.7042 & 3.6564 & 2.0734 & 4.3697 & (2.6035) & $(2.5944)$ & 5.5390 & 2.2449 & 4.3628 \\
\hline Prob. & 0.0000 & 0.0012 & 0.0486 & 0.0002 & 0.0153 & 0.0156 & 0.0000 & 0.0339 & 0.0002 \\
\hline
\end{tabular}



Adjusted R-squared $\quad 0.98404$ Sum squared resid $\quad 9.81 \mathrm{E}+09$
Durbin-Watson stat
F-statistic
1.773714
255.373

The other assumption is about the discount rate. In Figure 5 below, the discount rate is changed from $3 \%$ to $5 \%$ and the SSW series are gross and calculated by both the current and adaptive expectations methods, denoted by (cr) and (ae) respectively.

Figure 5: Estimation Results with 5\% Discount Rate

\begin{tabular}{lccccccccc}
\hline SSWG-cr & C & Y & SSWG & HW & FW & R & CRTP & DUMMY95 & Time \\
\hline Coefficient & 324,313 & 0.2837 & 0.0310 & 1.5474 & $(0.1819)$ & $(110,525)$ & 0.4846 & 54,604 & 7,958 \\
Std. Error & 55,581 & 0.0687 & 0.0128 & 0.3241 & 0.0626 & 39,364 & 0.0879 & 21,874 & 1,706 \\
t-Statistic & 5.8350 & 4.1266 & 2.4281 & 4.7748 & $(2.9077)$ & $(2.8078)$ & 5.5140 & 2.4963 & 4.6637 \\
Adjusted R-squared & 0.9849 & Durbin-Watson stat & 1.872753 & & & & \\
Sum squared resid & $9.30 \mathrm{E}+$ 09 F-statistic & & \multicolumn{2}{c}{269.4626} & & & &
\end{tabular}

\begin{tabular}{lccccccccc}
\hline SSWG-ae & C & Y & SSWG & HW & FW & R & CRTP & DUMMY95 & Time \\
\hline Coefficient & 334,354 & 0.2688 & 0.0313 & 1.4527 & $(0.1767)$ & $(106,627)$ & 0.5111 & 51,171 & 8,189 \\
Std. Error & 57,518 & 0.0728 & 0.0141 & 0.3283 & 0.0645 & 40,674 & 0.0905 & 21,887 & 1,818 \\
t-Statistic & 5.8130 & 3.6942 & 2.2285 & 4.4248 & $(2.7381)$ & $(2.6215)$ & 5.6474 & 2.3380 & 4.5045 \\
Adjusted R-squared & 0.9844 & Durbin-Watson stat & 1.7947 & & & & \\
Sum squared resid & $9.59 \mathrm{E}+$ 09 F-statistic & & 261.2627 & & & &
\end{tabular}

These results show that the sign and significance of the SSW variable are not sensitive to major assumptions. The DW statistics are between the lower and upper limits (with 0.01 significance), and therefore whether they have serial correlation problems is indeterminate. However, as indicated before, they have a simultaneity problem tested by the Hausman method ${ }^{42}$. When TSLS is used, the significance of SSW doesn't change but DW improves as shown in equation 7 in Figure 1

\subsection{Alternative Proxies for Social Security}

Even though SSW, the present value of future social security entitlements with survival probabilities, is the best proxy for people's perception of social security wealth, other alternative proxies can be used to test whether or not social security provisions affect consumption behaviors.

We used two proxies for social security: per capita real old-age benefits (SSA1) and a variable (SSA2) that is similar to one used by Barro (1978). This second proxy is calculated as a product of per retiree real old-age benefits, the cover ratio, ${ }^{43}$ and the total number of workers ${ }^{44}$. The results are presented in Figure 6 below show that the provision of social security has positive and statistically significant ${ }^{45}$ effects on consumption.

\footnotetext{
${ }^{42}$ The forecasted income and residuals are obtained by using the reduced form income equation, which includes instrumental variables. When Equation 6 in Figure 1 was re-estimated with the forecasted income and residuals, I found that residuals are statistically significant with the t-value of 8.3.

43 The cover ratio is the ratio of the number of workers covered by social security to the total employment.

${ }^{44}$ The data on employment is from SIS and Bulutay (1995).

45 The second proxy is significant with $10 \%$ confidence level.
} 
Figure 6: Estimation Results with Alternative Proxies

\begin{tabular}{lccccccccc}
\hline Variable & C & Y & SSA1 & HW & FW & R & CRTP DUMMY95 & Time \\
\hline Coefficient & 366,170 & 0.2856 & 1.5418 & 1.3328 & $(0.2204)$ & $(110,868)$ & 0.5286 & 59,182 & 6,571 \\
Std. Error & 56,721 & 0.0648 & 0.5205 & 0.3132 & 0.0649 & 37,299 & 0.0858 & 21,097 & 1,444 \\
t-Statistic & 6.4557 & 4.4097 & 2.9623 & 4.2560 & $(3.3967)$ & $(2.9724)$ & 6.1606 & 2.8052 & 4.5501 \\
Prob. & 0.0000 & 0.0002 & 0.0066 & 0.0003 & 0.0023 & 0.0065 & 0.0000 & 0.0096 & 0.0001
\end{tabular}

Adjusted R-squared $\quad 0.9862$ Durbin-Watson stat $\quad 1.9077$

Sum squared resid $\quad 8.51 \mathrm{E}+09$ F-statistic 294.87

\begin{tabular}{lccccccccc}
\hline Variable & C & Y & SSA2 & HW & FW & R & CRTP & DUMMY95 & Time \\
\hline Coefficient & 306,470 & 0.2927 & 0.2720 & 1.5580 & $(0.1514)$ & $(112,062)$ & 0.4705 & 48,716 & 8,301 \\
Std. Error & 57,059 & 0.0716 & 0.1440 & 0.3382 & 0.0619 & 41,385 & 0.0914 & 22,347 & 1,988 \\
t-Statistic & 5.3711 & 4.0867 & 1.8888 & 4.6067 & $(2.4470)$ & $(2.7078)$ & 5.1470 & 2.1800 & 4.1743 \\
Prob. & 0.0000 & 0.0004 & 0.0706 & 0.0001 & 0.0218 & 0.0120 & 0.0000 & 0.0389 & 0.0003
\end{tabular}

Adjusted R-squared $\quad 0.98363$ Durbin-Watson stat $\quad 1.808979$

Sum squared resid $\quad 1.01 \mathrm{E}+10 \mathrm{~F}$-statistic $\quad 248.9205$

\subsection{Tests for Spurious Regressions}

A spurious regression model is one in which the dependent and independent variables are non-stationary, but not cointegrated. Granger and Newbold (1974) observed that even when the series are independent of each other, the classical spurious regressions had very high $R$-squared (R2) statistics with very low Durbin-Watson (DW) statistics. Since our regressions use time-series data, we need to test whether the high degree of fit in the estimations, as measured by high R2 and significant t-tests, is a result of "spurious significance". The time series literature in our subject implicitly uses DW statistics to detect the "spurious significance” problem. Phillips (1986) developed an asymptotic theory that the DW statistic in spurious regressions converges in probability to zero as the sample size increases. ${ }^{46}$

In order to test whether the variables used in our regressions are stationary around a linear trend or have stochastic trends, we first perform the augmented DickeyFuller test (ADF) for the presence of unit roots in the variables. As seen in Table 4 below, Old, Young, and Urban are I(2); Rintr and Inf are I(0) and the rest are I(1).

\footnotetext{
${ }^{46}$ The Cointegrating Regression Durbin-Watson (CRDW) test uses the DW statistics, $d$, obtained from the cointegrating regression to test the null hypothesis of $d=0$. If $d$ could be approximated by $2(1-\rho)$ and the sample first-order correlation coefficient, $\rho$, is about 1 (indicating a unit root in the error term), $d$ will be zero. (Sargan and Bhargava 1983). Therefore, a low DW statistics could be taken as a strong sign of spurious significance. Nevertheless, Maddala and Kim (1998) indicate that regressions with high DW statistics do not necessarily ensure that we do not estimate spurious regressions especially if the sample size is relatively small.
} 
Table 4: Augmented Dickey-Fuller (ADF) Test Results for Unit Roots

\begin{tabular}{|c|c|c|c|c|c|c|c|c|c|}
\hline \multirow[b]{2}{*}{ Variables } & \multicolumn{3}{|l|}{ Level } & \multicolumn{3}{|c|}{ 1st Difference } & \multicolumn{3}{|c|}{ 2nd Difference } \\
\hline & ADF t-test & Lag & $c \& t$ & ADF t-test & Lag & $c \& t$ & ADF t-test & Lag & c\&t \\
\hline CONS & -3.511099 & 0 & $\mathrm{ct}$ & -7.447739 & 0 & & & & \\
\hline$Y$ & -2.051519 & 0 & $\mathrm{ct}$ & -5.749789 & 0 & & & & \\
\hline SSWG & -0.805777 & 2 & $\mathrm{ct}$ & -4.103717 & 1 & & & & \\
\hline SSWN & -0.246096 & 2 & $\mathrm{ct}$ & -4.909395 & 1 & $\mathrm{ct}$ & & & \\
\hline$H W$ & -1.953167 & 1 & $\mathrm{C}$ & -4.332534 & 0 & & & & \\
\hline$F W$ & -1.875746 & 1 & $\mathrm{ct}$ & -2.281867 & 1 & & & & \\
\hline Rintr & -2.698091 & 0 & & & & & & & \\
\hline CRTP & -3.294444 & 1 & $\mathrm{ct}$ & -5.305846 & 1 & & & & \\
\hline Inf & -4.720763 & 1 & & & & & & & \\
\hline Old & -2.091723 & 1 & $\mathrm{ct}$ & -1.250801 & 0 & & -5.496650 & 0 & \\
\hline Young & -2.710636 & 1 & $\mathrm{ct}$ & -0.991528 & 0 & & -5.469800 & 0 & \\
\hline$L F P R$ & -1.896337 & 0 & $\mathrm{ct}$ & -6.240468 & 0 & c & & & \\
\hline Un & -3.011565 & 1 & C & -4.700727 & 0 & & & & \\
\hline Urban & -2.310802 & 1 & $\mathrm{ct}$ & -0.916081 & 0 & & -5.477230 & 0 & \\
\hline SSWGAE & -0442997 & 1 & $\mathrm{ct}$ & -4.640900 & 1 & $\mathrm{ct}$ & & & \\
\hline SSWG5 & -0.708768 & 2 & $\mathrm{ct}$ & -4.021000 & 1 & & & & \\
\hline SSWG5AE & -0.290429 & 2 & $\mathrm{ct}$ & -3.757103 & 1 & & & & \\
\hline SSA1 & -0.933166 & 1 & $\mathrm{ct}$ & -2.835510 & 1 & & & & \\
\hline SSA2 & -1.539332 & 1 & $\mathrm{ct}$ & -3.580142 & 0 & & & & \\
\hline LCONS & -2.712982 & 1 & $\mathrm{ct}$ & -7.328273 & 0 & & & & \\
\hline LCRTP & -3.554406 & 1 & $\mathrm{ct}$ & -5.418992 & 1 & & & & \\
\hline$L H W$ & -2.098230 & 1 & $\mathrm{C}$ & -3.931846 & 0 & & & & \\
\hline$L F W$ & -2.105252 & 0 & $\mathrm{ct}$ & -5.397414 & 0 & c & & & \\
\hline LSSWG & -1.797932 & 1 & $\mathrm{ct}$ & -4.334073 & 1 & & & & \\
\hline$L Y$ & -2.443473 & 0 & $\mathrm{ct}$ & -5.915426 & 0 & & & & \\
\hline
\end{tabular}

Notes: The test results are obtained by Eviews. Bold numbers are significant at $5 \%$ level to reject the null hypothesis states the presence of unit root. We start with four lags in each variable's ADF regression. The longest lag is determined by its significance at $10 \%$. The existence of a constant and time trend in the $\mathrm{ADF}$ regressions is indicated by c and $\mathrm{t}$ respectively. All variables are as defined before. $A E$ and 5 attached to SSWG indicate the adaptive expectation method used in the benefit ratio and $5 \%$ discount rate respectively. The variables that start with $L$ (except $L F P R$ ) are the log transformation of the original ones.

Any equilibrium relationship among a set of nonstationary variables implies that their stochastic trends must be linked. This linkage among the stochastic trends necessitates that the variables be cointegrated. Therefore, a key assumption of our consumption model is that the disturbance term is stationary. Since our interest in the current context is not to estimate coefficients of the cointegrating vector, we use a residual-based test for cointegration in a single equation suggested by Engle and Granger (1987) to investigate if the residuals in our regressions are stationary. ${ }^{47}$ We perform the ADF test on our reference regression (Equation 6) in Figure 1 and on the other equations from Figure 2 to 6. As Enders (1995) argues, even though the order of integration among variables is important to perform the test, what is ultimately

\footnotetext{
${ }^{47}$ We have also used the Johansen (1988) test for the presence of multiple cointegrating vectors. The results confirm the residual-based ADF test.
} 
important is whether or not a combination of variables are cointegrated, and this could be achieved through combination of subsets rather than individual series. ${ }^{48}$ In our case, since Rintr is $I(0)$, we test whether the same equations (including only $I(1)$ variables) without Rintr are $C I(1,1)$.

The test results in Table 5 below show that the subsets of $I(1)$ variables are $C I(1,1)$ at $5 \%$ significance level except for Figure 2, which is $C I(1,1)$ at $10 \%$. We conclude that since a linear combination of any of these subsets, which are $I(0)$, with Rintr, which is $I(0)$, can only generate a stationary process, the resulting regressions are not spurious.

\section{Table 5: Residual-Based Cointegration Tests}

Figure1-6 (Cons, $Y$, SSWG, HW, FW, CRTP)

Figure2 (LCons, LY,LSSWG, LHW, LFW, LCRTP)

Figure3 (Cons, $Y, S S W N, H W, F W, C R T P$ )

Figure4 (Cons, $Y$, SSWGAE, HW, FW, CRTP)

Figure5-1 (Cons, Y, SSWG5, HW, FW, CRTP)

Figure5-2 (Cons, Y, SSWGAE5, HW, FW, CRTP)

Figure6-1 (Cons, $Y$, SSA1, HW, FW, CRTP)

Figure6-2 (Cons, $Y$, SSA2, HW, FW, CRTP)

$\begin{array}{cc}\text { ADF t-test } & \text { Lag } \\ -6.0712 & 1 \\ -5.5767 & 1 \\ -6.0629 & 1 \\ -5.8921 & 1 \\ -6.0586 & 1 \\ -5.9070 & 1 \\ -5.8456 & 1 \\ -5.9902 & 1\end{array}$

Notes: The results are obtained by Eviews. The null hypothesis states no cointegration among the variables. MacKinnon (1991) provides response surface equations for critical values of cointegration tests using ADF framework for different sample sizes, significance levels, and number of variables in the cointegrating equation. Given six stochastic explanatory variables with a constant and time trend in our cointegrating equations, the critical values calculated for the sample size of 34 are $\mathbf{- 6 . 4 6 2 1}$ for $1 \%$, $\mathbf{5 . 5 9 8 7}$ for $5 \%$, and

$\mathbf{- 5 . 1 8 3 6}$ for $10 \%$. Optimal lag is chosen using Akaike information criterion (AIC). Each equation has a dummy for the year 1995.

\section{Conclusion}

This paper investigates whether or not the public social security system affects consumption in a developing country, Turkey. It uses a time-series aggregate consumption model based on the life-cycle hypothesis. In order to quantify a social security variable in the model, the social security wealth series for Turkey were constructed (in a separate study). These series indicate that the social security wealth is a major component of household wealth.

The empirical tests here show that SSW has a positive effect on consumption. Moreover, when the insignificant variables are removed it becomes statistically significant. The sensitivity of these results was tested against the major assumptions

\footnotetext{
${ }^{48}$ Enders $(1995,411)$ gives an example: "Suppose that $x_{1 t}$ and $x_{2 t}$ are $I(2)$ and $x_{3 t}$ is I(1). If $x_{1 t}$ and $x_{2 t}$ are $C I(2,1)$, there exists a linear combination of the form $\beta_{1} x_{1 t}+\beta_{2} x_{2 t}$ that is $I(1)$. It is possible that this combination of $x_{1 t}$ and $x_{2 t}$ is cointegrated with $x_{3 t}$ such that the linear combination of $\beta_{1} x_{1 t}+\beta_{2} x_{2 t}+\beta_{3} x_{3 t}$ is stationary”.
} 
embedded in the SSW calculation. The test results confirm that the significance level of SSW does not change.

In addition to the SSW series, "Income from Dwellings" and "Money and Quasi-money”, M2, are used as proxies for housing wealth and financial wealth respectively. The first proxy for housing wealth has a significant positive effect on consumption. This is consistent with the fact that people under the conditions of shallow financial markets and high political instability invest heavily in housing. However, high bequest motives, together with the lack of proper financial instruments, such as mortgages, may reduce its power, as an asset, on consumption. Therefore, the direct and imputed income from dwellings may reflect the "true" effects of housing wealth on consumption, as we found in our regressions.

Although significant, the sign of financial assets $(F W)$ contradicts the model. However, as noted before, through the price levels, the real money balance could be negatively related to consumption. For example, if nominal interest rates are not so responsive to a decline in inflation, as the inflation goes down, it pushes saving up by increasing real interest rates.

Even though time-series studies have several limitations, in order to assess the quantitative importance of the positive coefficient of SSW variable, one may want to see the magnitude of the reduction in Turkish national saving. With different assumptions and social security wealth definitions, the coefficient ranges from 0.0165 (Figure 3 ) to 0.0313 (Figure 5). In other words, every additional $1 \mathrm{TL}$ of SSW increases the total consumption between 0.0165 and 0.0313 TL. For instance, if we take 2003 and SSWN (283,310,716 million TL, with 1987 prices) the consumption is higher 4,816,282 million TL $(283,310,716$ X 0.0165$)$ than would be the case without any social security program. If we consume instead of saving by this amount, the private saving falls. Since Turkey has a PAYG system, this reduction is not offset by any increase in the public saving. As a result, the national saving falls as well. Moreover, the private disposable income is reduced by the total contributions (taxes for the old-age, disability and survivor insurance). The total premiums paid in 2003 to SSK, EM and BK is 5,943,740 million TL (with 1987 prices). Since the marginal propensity to save out of NPrvDI is around 72\% (Figure 1, Equation 6), we can conclude that social security contributions also reduce saving by 4,279,493 million TL. Therefore, because of the PAYG system, the total saving is lower 9,095,775 million TL $(4,279,493+4,816,282)$ than would be the case without a PAYG system in Turkey. National saving in 2003 (by SPO, in 1987 prices, million TL):

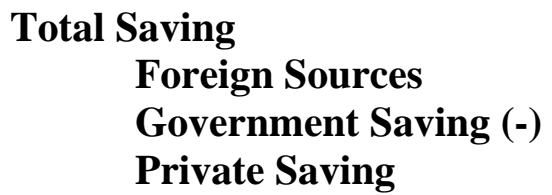

\section{$29,482,465$}

$5,256,678$

$5,743,524$

$29,969,310$

Without considering the negative effects of the current PAYG system on public saving, this implies a 24-percent reduction (9,095,775/(9,095,775 + 29,482,465)) in Turkish national saving in 2003. This reduction is calculated by SSWN and its coefficient, 0.0165. However, if we use SSWG and its coefficients estimated with different 
assumptions, the reduction becomes higher than 24\%. Feldstein $(1974,1996)$ makes the same calculation and finds that social security depresses personal saving 30-60 percent for the US.

As Auerbach and Kotlikoff (1983) point out, time-series studies have several drawbacks in estimating the effects of social security on saving. Moreover, the empirical analyses could be extended to include some omitted variables, such as external and government savings by disaggregating the income variable ${ }^{49}$. Likewise, the SSW variable could also be improved by doing further "fine-tunings". Lastly, as commonly used in investigations, error correction models with flexible distributed lags can be applied.

But this paper's goal was limited: determining whether or not a time-series aggregate consumption model for a developing country, Turkey, could provide relatively consistent evidence that the social security wealth has negative effects on saving as argued in the literature for developed countries. Turkey has a generous public social security system. The results, with both social security proxies, show that social security wealth has a significant positive effect on consumption, and this could be interpreted that public social security reduces saving in Turkey.

If social security provisions reduce saving, as shown here, there should be an "opportunity cost” of having an unfunded social security system, regardless of whether or not it is in balance. Therefore, reforms ultimately need to address two problems together: financial sustainability of social security systems over the coming decades and their negative effects on saving.

\footnotetext{
${ }^{49}$ Since an increase in external saving raises the total sources available for the private sector, it might be positively related to consumption. Besides, given the value of government spending, an increase or decrease in government saving may have a direct effect on the total sources available for the private sector. The effects of government saving on consumption could be explained from a national accounting perspective. As you may recall, we define the net private disposable income (NPrvDI) as follows: 


\section{Appendix: Social Security Wealth Series for Turkey}

SSW is the aggregate present value of future social security annuities with survival probabilities anticipated by people. Since it's a highly concentrated work, we constructed the SSWG and SSTX series for Turkey in a different study (Author, 2005). Therefore, we present here only the basic logic of the calculations for the net and gross social security wealth (SSWN and SSWG), which is very similar to one calculated by Feldstein (1974).

Benefits (Future Annuities -- SSWG):

- If an individual at the age of $(a)$ in year $(t)$ survives to age $r a^{50}$, and if his current real disposable income, $Y_{(a, t)}$, grows at a constant rate of growth, $g$, then he'll have a disposable income at the age of $r a$ : $Y_{t+r a-a}=Y_{t}(1+g)^{(r a-a)}$

- In order to find the first annual social security benefit at $r a$ for that particular individual, we look at the past data and come up with a benefit factor, $b f$, which is basically a ratio of per retiree annual old-age benefits to per capita NPrvDI ${ }^{51}$.

- Given that factor, the individual will be entitled to his first annual social security benefit at age $r a$, which is $B_{(a, t)}=b f_{t} Y_{t}(1+g)^{(r a-a)}$.

- We assume that real annuities grow after $\mathrm{ra}$ by $g a^{52}$ until the truncated maximum age of 85 .

- Given the survival probabilities $S_{(i, j)}$ for that particular individual, the actuarial present value can be calculated at the age of $r a$, where $S_{(i, j)}$ presents the probability of living at least up to the age of $j$, given that the person lived to age i.

- With the personal discount rate $(d)^{53}$ for future real incomes, the present value calculation becomes at the age of ra:

$$
\sum_{n \geq r a} S_{(r a, n)} B_{(a, t)}(1+g)^{(n-r a)}(1+d)^{-(n-r a)}
$$

- At time $(t)$, after substituting $B_{(a, t)}$, the person has

$$
A_{(a, t)}=b f_{t} Y_{t} S_{(a, r a)}[(1+g) /(1+d)]^{(r a-a)} \sum_{85 \geq r a} S_{(r a, 85)}[(1+g) /(1+d)]^{(85-r a)}
$$

which also includes survival probabilities between $r a$ and age $a$ at time $(t)$.

- We calculated the gross SSW annually by summing the wealth for each age groups an genders in six groups: workers, workers' wives, old-age retirees, oldage retirees' wives, disability retirees and survivors.

\section{Taxes (future social security tax liabilities - SSTX):}

- If the same individual at the age of $(a)$ in year $(t)$ survives to age $r a$, and if his

\footnotetext{
${ }^{50} \mathrm{We}$ assume that the retirement age is not endogenous. That is, people get retired at the same age, which is 55 for both genders in our calculations.

${ }^{51}$ We use three different expectation methods for benefit (and tax) factors: average (constant) factors, the adaptive expectation method (with arbitrarily chosen weights: 50\% for the first year and 25\% for the last two years each) and current benefit (and tax) factors method.

${ }^{52}$ We assumed that the growth rate of real annuities can be $2 \%$ or zero.

${ }^{53}$ We used 3\% and 5\% alternatively.
} 
current real disposable income, $Y_{(a, t)}$, grows at a constant rate of growth, $g$, then the present value of all his future taxes until age $r a$ is

$T A X_{a, t}=\sum_{m=a}^{r a} S_{a, m} \theta_{t+m-a} Y_{t}[(1+g) /(1+d)]^{m-a}$, where $\theta$ is the ratio of social

security taxes (Old-age, disability and survival - ODS) per worker to per capita disposable income and the person expects that at the age $m$ he will pay a tax of $T_{t+m-a}=\theta_{t+m-a} Y_{t}(1+g)^{m-a}$. We compute the social security tax liabilities (SSTX) for a given year by summing the tax liability of current working men and working women.

When we subtract the present value of future taxes (SSTX) from the present value of benefits $(S S W G)$, we find $S S W N$ : $S S W N_{t}=S S W G_{t}-S S T X_{t}$. Aggregated SSWG and SSTX formulas for each group are given in Figure 7. Assumptions, data sources and more detail can be found in Author (2005). 
Figure 7: Aggregate SSWG and SSTX Formulas for Turkey

$\underline{\text { SSWG }}$

Workers $\quad S S W G_{t}=\sum_{a=15}^{r a}\left(W_{a, t} / P_{a, t}\right)^{G} C_{t}^{G} b f_{t}^{G} Y_{t} S_{(a, r a)}^{G}[(1+g) /(1+d)]^{(r a-a)} \sum_{n=r a}^{85} S_{(r a, n)}^{G}[(1+g a) /(1+d)]^{(n-r a)}$

Workers' Wives

$S S W G=\sum_{a=15}^{r a}\left(W_{a, t} / P_{a, t}\right)^{M} C_{t}^{M} b f_{t}^{M} S r^{M} Y_{t}(B R)\left(S_{(a-3, r a)}^{F}\right)\left(1-S_{(a, r a)}^{M}\right)[(1+g) /(1+d)]^{(r a-a)} \sum_{n=r a}^{85} S_{(r a, n-3)}^{F}[(1+g a) /(1+d)]^{(r a-n)}$

Plus

$\sum_{a=15}^{r a}\left(W_{a, t} / P_{a, t}\right)^{M} C_{t}^{M} b f_{t}^{M} S r^{M} Y_{t}(B R)\left(S_{(a-3, r a)}^{F}\right)\left(S_{(a, r a)}^{M}\right)[(1+g) /(1+d)]^{(r a-a)} \sum_{n=r a}^{85}\left(S_{(r a, n-3)}^{F}\right)\left(1-S_{(r a, n)}^{M}\right)[(1+g a) /(1+d)]^{(n-r a)}$

Retirees $\quad S S W G_{t}=N_{t}^{G} A V B_{t}^{G} \sum_{n=\text { ara }}^{85} S_{(\text {ara }, n)}^{G}[(1+g a) /(1+d)]^{(n-a r a)}$

Retirees' Wives $S S W G_{t}=N_{t}^{M}\left(s r^{M}\right)(B R) A V B_{t}^{M} \sum_{n=\text { ara }}^{85}\left(S_{(\text {ara }, n-3)}^{F}\right)\left(1-S_{(\text {ara }, n)}^{M}\right)[(1+g a) /(1+d)]^{(n-a r a)}$

Disability Retirees $\quad S S W G_{t}=N D_{t}^{G}\left(A B D_{t}\right) \sum_{n=a r a}^{85} S_{(\text {ara }, n)}^{G}[(1+g a) /(1+d)]^{(n-a r a)}$

Survivors -- Wives $\quad S S W G_{t}=N S_{t}^{w}\left(A B S W_{t}\right) \sum_{n=a r a}^{85} S_{(\text {ara }, n)}^{F}[(1+g a) /(1+d)]^{(n-a r a)}$

Survivors-Orphans $\quad S S W G_{t}=N S_{t}^{O}\left(A B S O_{t}\right) \sum_{n=a r a}^{a r a+10} S_{(a r a, n)}^{F}[(1+g a) /(1+d)]^{(n-a r a)}$

$\underline{\text { SSTX }}$

Workers $\quad \operatorname{SSTX}_{t}=\sum_{a=15}^{r a}\left(W_{a, t} / P_{a, t}\right)^{G} C_{t}^{G} \theta_{t}^{G} Y_{t} \sum_{m=a}^{r a} S_{a, m}^{G}[(1+g) /(1+d)]^{m-a}$

$M=$ Male, $F=$ Female, $G=$ Gender,$t=$ year, $a=$ age at time $t, r a=$ retirement age, ara $=$ average age for retirees, $m=$ age between current age $a$ and retirement age ra, $n=$ age between retirement age ra and the maximum age, 85, $w=$ wives, $\mathrm{O}=$ orphans, $\mathrm{d}=$ personal discount rate, $\mathrm{g}=$ growth rate of real reference income, $\mathrm{ga}=$ growth rate of real annuities, $W=$ number of employers, $P=L F P R$ adjustment factor, $C=$ ratio of active insured employment to total employment, $\theta=$ tax factor, $Y=$ reference income, $A V B=$ per retiree average old-age benefit, $A B D=$ per retiree average disability benefit, $A B S W=$ per retiree (wives) average survivors benefit, $A B S O=$ per retiree (orphans) average survivors benefit $S_{(a, m)}=$ survival probability of a person who lives up to age $m$, given that she/he lived up to age $a$, bf $=$ benefit factor, $N=$ number of old-age beneficiaries, $s r=\%$ of male married, $B R=$ discount ratio for benefits passed from worker or retirees to survivors. 


\section{References:}

Akkoyunlu, S. (2002). Modeling Consumers' Expenditure in Turkey, 1962-1994. School of Economics, Seminar Series 2005, University of Cape Town, http://www.commerce.uct.ac.za/Economics/Seminars/

Ando, A. and Modigliani, F. (1963). The Life Cycle Hypothesis of Saving: Aggregate Implications and Tests, The American Economic Review, Vol.53.

Author (2005). Social Security Wealth Series for Turkey: Calculations, Assumptions and Data Resources.

Auerbach, A. and Kotlikoff, L. (1983). An Examination of Empirical Test of Social Security and Savings. In Helpman, Elhanan, Razin, Sadka (eds.), Social Policy Evaluation: an economic perspective, p. 161-79.

Barro, R. (1974). Are Government Bonds Net Wealth? Journal of Political Economy, vol. 82(6).

Barro, R. (1978). The Impact of Social Security on Private Saving: Evidence from New the US Time Series, American Enterprise Institute, AIE Studies 199.

Barro, R. (1989). The Ricardian Approach to Budget Deficits, Journal of Economic Perspectives, vol. 3(2).

Blake, D. (2004). The Impact of Wealth on Consumption and Retirement Behaviour in the UK. Applied Financial Economics. Vol.14.

Blinder, A., Deaton, A., Hall, R., and Hubbard, R. (1985). The Time Series Consumption Function Revisited. Brookings Papers on Economic Activity, Vol. 1985, No. 2.

Boyle, P. and Murray, J. (1979). Social Security and Private Saving in Canada. Canadian Journal of Economics, Vol.10.

Browning, M.J. (1982). Saving and Pensions: Some UK Evidence. Economic Journal. Vol. 92.

Bulutay, T. (1995). Employment, unemployment and wages in Turkey, ILO

Campbell, J. and Mankiw, G. (1989). Consumption, Income, and Interest Rates: Reinterpreting the Time Series Evidence. NBER Working Paper, No. 2924.

CBO memorandum, (1998). Social Security and Private Saving: A Review of the Empirical Evidence. Congressional Budget Office -USA. 
Coates, D. and Humphreys, B.R. (1999). Social Security and Saving: A Comment. National Tax Journal. Vol.52, No.2

Darby, M. R. (1979). The Effects of Social Security on Income and the Capital Stock. The American Enterprise Institute for Public Policy Research, Washington, D.C.

Enders, W. (1995). Applied Econometric Time Series. Jon Wiley \& Sons, Inc.

Engen, E. and Gale, W. (1997). Effects of Social Security Reform on Private and National

Saving. Social Security Reform: Links to Saving, Investment and Growth, Federal Reserve Bank of Boston. June.

Engle, R.F. and Granger C.W. (1987). Co-integration and Error Correction: Representation, Estimation and Testing. Econometrica. Vol. 55.

Feldstein, M. (1974). Social Security, Induced Retirement, and Aggregate Capital Accumulation. Journal of Political Economy. Vol.82, No.5.

Feldstein, M. (1976a). Social Security and Saving: The Extended Life Cycle Theory. Modern public Finance National Tax Journal. Vol.66, No.2.

Feldstein, M. (1976b). Social Security and Distribution of Wealth. Journal of the American Statistical Association. Vol.71 No.356.

Feldstein, M. (1978). Reply. American Enterprise Institute, AIE Studies 199.

Feldstein, M. (1982). Social Security and Private Saving: Reply. Journal of Political Economy. Vol.90, No.3.

Feldstein, M. (1996). Social Security and Saving: New Time-Series Evidence. National Tax Journal. Vol.49, No.2.

Finkelstein, A. and Poterba, J. (2004). Adverse Selection in Insurance Markets: Policyholder Evidence from the U.K. Annuity Market. Journal of Political Economy. Vol.112.

Granger, C.W.J. and Newbold, P. (1974). Spurious Regressions in Econometrics, Journal of Econometrics. Vol.2.

Hamburger, W. (1955). The Relation of Consumption to Wealth and the Wage Rate, Econometrica, Vol.23.

Johnston, J. and Dinardo, J. (1997). Econometric Methods, $4^{\text {th }}$ Edition. McGraw-Hill. 
Kormendi, R. (1983). Government Dept, Government Spending, and Private Sector Behavior. The American Economic Review, Vol.73.

Lee, M.L. and Chao S.W. (1988). Effects of Social Security on Personal Saving. Economic Letters. Vol.28.

Leimer, D.R. and Lesnoy, S.D. (1982b). Social Security and Private Saving: New Time-Series Evidence. Journal of Political Economy. Vol.90, No.3.

Leimer, D.R. and Lesnoy, S.D. (1980). Social Security and Private Saving: A Reexamination of the Time-Series Evidence Using Alternative Social Security Wealth Variables. Social Security Administration, working paper No.19.

Maddala, G.S. and Kim, I.M. (1998). Unit Roots, Cointegration, and Structural Change. Cambridge University Press.

MacKinnon, J.G. (1991). Critical Values for Cointegration Tests in "Long Run Economic Relationships” by R.F. Engle and C.W.J Granger. Oxford University Press, pp.169-210.

Magnussen, Kunt A. (1994). Old-Age Pensions, Retirement Behavior and Personal Saving: A Discussion of the Literature. Statistics Norway, Social and Economic Studies.

Markowski, A. and Palmer, E. (1979). Social Insurance and Saving in Sweden. In von Furstenberg: Social Security versus Private Saving, Cambridge, Massachusets: Ballinger Publishing Company.

Meguire, P. (1998). Comment: Social Security and Private Savings, National Tax Journal. No.2.

Mehra, Yash P. (2001). The Wealth Effect in Emprical Life-Cycle Aggregate Consumption Equations. Federal Reserve Bank of Richmond Economic Quarterly Volume 87/2 Spring.

Ministry of Labor and Social Security, (July 29, 2004). "Proposal for Reform in the Social Security System (Draft Text).

Modigliani, F. (1986). Life Cycle, Individual Thrift, and the Wealth of Nations. The American Economic Review, Vol.76, No.3.

Munnell, A. (1974). The Impact of Social security on Personal Savings. National Tax Journal. Vol.27.

Novos, E. (1989). Social Security Wealth and Wealth Accumulation: Further Microeconomic Evidence. The Review of Economics and Statistics. Vol.71, No.1. 
OECD (1998). The Macroeconomics of Ageing, Pensions and Savings: A survey, working paper no: 200.

OECD (2005). Pensions at a Glance: Public Policies across OECD Countries. OECD Publishing.

Ozcan Metin, K.; Gunay, A.; Ertac, S. (2003). Determinants of private saving behaviour in Turkey. Applied Economics, 35.

Pfaff, M., Hurler, P. and Dennerlein, R. (1979). Old-Age Security and Saving in the Federal Republic of Germany. In von Furstenberg (ed.). Social Security versus Private Saving, Cambridge, Massachusetts. Ballinger Publishing Company.

Phillips, P.C.B. (1986). Understanding Spurious Regressions in Econometrics. Journal of Econometrics. Vol.33.

Rossi, N. and Visco, I. (1995). National Savings and Social Security in Italy. Ricerche Economiche. Vol. 49.

Sargan, J.D. and Bhargava, A.S. (1983). Testing Residuals from Least-Squares Regression for Being Generated by the Gaussian Random Walk. Economterica. Vol.51.

Seidman, L. (1985). A General Equilibrium Critique of Feldstein's Social Security Estimate. Eastern Economic Journal, Vol. XI, No.2.

Seidman, L. (1999). Funding Social Security: A Strategic Alternative. Cambridge University Press.

The World Bank Report, (2000). Turkey Country Economic Memorandum. Report Number 20657-TU.

The World Bank Country Study, (2003). Non-Bank Financial Institutions and Capital Markets in Turkey.

TUSIAD (Turkiye Sanayicileri ve Isadamlari Dernegi) Report (2004). Turk Emeklilik Sisteminde Reform. Yayin No. TUSIAD-T/2004-11/382. 